\title{
Microbial inoculation during composting improves productivity of sun mushroom (Agaricus subrufescens Peck)
}

\author{
Vinícius Reis de Figueirêdo ${ }^{1 *}$, Emerson Tokuda Martos ${ }^{2}$, Félix Gonçalves de Siqueira ${ }^{3}$, \\ William Pereira Maciel ${ }^{2}$, Romildo da Silva ${ }^{2}$, Danny Lee Rinker ${ }^{4}$ and Eustáquio Souza Dias ${ }^{2}$ \\ ${ }^{1}$ Instituto Federal de Educação, Ciência e Tecnologia Baiano - IF BAIANO, Km 2,5 da BR 420, Rod. Santa Inês - \\ Ubaíra, Zona Rural - Santa Inês/BA, Brazil. CEP. 45320-000. \\ ${ }^{2}$ Department of Biology; Universidade Federal de Lavras - UFLA, Caixa Postal, 3037, CEP. 37200-000, Lavras/MG, \\ Brazil. Phone: +5535 3829-1613. \\ ${ }^{3}$ Laboratory of Industrial Microbiology and Enzymology, Department of Biotechnology, Universidade Federal da Bahia, \\ Vitoria da Conquista/BA, Brazil. \\ ${ }^{4}$ University of Guelph - Vineland Campus, 4890 Victoria Avenue North, P.O. Box 7000, Vineland Station, \\ Ontario, Canada LOR 2E0.
}

Accepted 26 August, 2013

\begin{abstract}
The aim of this research was to evaluate the application of different microbial additives during composting, on some parameters of the production of Agaricus subrufescens. Compost was prepared over two weeks with ammonia assimilating bacterial and a thermophillic fungus as microbiological additives. These additives were introduced during two week composting to promote greater selectivity of the substrate cultivation and provide increased productivity of mushrooms. The data shows that the microbiological additives used in composting had a significantly higher productivity, when compared to treatments without additives. These species can be used as microbiological additives in $A$. subrufescens cultivation.
\end{abstract}

Key words: Agaricus subrufescens, microbial additives, productivity, composting, mushroom sun.

\section{INTRODUCTION}

The conventional composting process for cultivation of Agaricus subrufescens (also known as $A$. blazei or $A$. brasiliensis) (Wasser et al., 2002, 2005; Kerrigan, 2005, 2007; Wasser, 2007; Dias et al., 2008) is derived from the method developed by Sinden and Hauser (1950) used for the cultivation of Agaricus bisporus. This method has two phases. The first one is called phase I or "outdoor", in which the raw materials are wetted and stacked in piles, and turned over a few times, for approximately two weeks. The second stage, called phase II or "indoor" is carried out in an appropriate tunnel to control temperature and aeration. Phase II has two objectives: Pasteurization (to eliminate pests, diseases and competitors) and conditioning (to create adequate conditions for mushroom growth and suppressive conditions for undesirable microorganisms). Therefore, the substrate must be pasteurized at $60^{\circ} \mathrm{C}$ for $6 \mathrm{~h}$ and conditioned at $45^{\circ} \mathrm{C}$ up to 14 days or until ammonia dissipation (Straatsma et al., 2000; Eira, 2003; Oei, 2003; Chang and Miles, 2004; Salar and Aneja, 2007). 
Acording to Siqueira et al. (2011), the initial nitrogen concentration can also influence the $A$. subrufescens productivity, because the high initial ammonia concentration at the end of Phase $I$ is favorable for thermophilic microorganisms' nutrition, which aids in substrate degradation. However, on the other hand, at the end of Phase II, ammonia must be almost completely dissipated, due to its toxicity to the mycelial growth of the Agaricus mushrooms. However, there are evidences for different behaviors between these two species ( $A$. subrufescens and $A$. bisporus) for the initial $\mathrm{C} / \mathrm{N}$ ratio (Matute et al., 2011; Dias, 2010). In spite of using the same strategy for the compost production, these are two different species ( $A$. subrufescens and $A$. bisporus), which obviously present different requirements regarding the compost quality, casing layer, temperature among others (Dias, 2010).

Considering that thermophilic microorganisms convert free ammonia into microbial protein during the compost conditioning process, the performance of these microorganisms play a crucial role in the preparation of the compost, making it more appropriate for mycelial growth (Chang and Miles, 2004; Bechara, 2007). Among different species of thermophilic fungi found in the mushroom compost, the fungus Scytalidium thermophilum is reported as being the dominant specie during Phase II (Straatsma et al., 1994), although alterations occur in the population dynamics during this process (Vajna et al., 2010).

Besides the thermophilic fungi, prokaryotes are present and probably play an important role during the composting process. The actinobacteria stands out for producing a white-grayish mass throughout the compost, at the end of Phase II, evidencing its colonization on the compost (Silva et al., 2009). In agreement with Ahlawat and Vijay (2010), Staphylococcus and Bacillus species can be used as microbial inoculants in the composting process seeking the cultivation of $A$. bisporus. According to the authors, the use of those bacteria in the mushroom compost provided an earlier harvest and an increase in productivity. According to the same authors, the extracellular enzymes produced by the bacteria can convert agroindustrial residues into a more selective and appropriate compost for the mushroom production.

However, conventional phase II requires a tunnel in which the temperature is properly controlled for pasteurization and the conditioning stages of the compost. Considering the investment and cost of this process, the small producers pay a high price to purchase the compost, which makes this activity not economically viable for small mushroom growers in developing countries. An alternative could be the production of the compost by the small producers, using a simpler, less expensive process which is the long composting, followed by steam pasteurization. However, that strategy has a great disadvantage of low compost quality obtained without phase II.
Based on the above, the objective of this work was to evaluate the use of microbial inoculants during composting seeking the production of compost for cultivation of the $A$. subrufescens mushroom, using the composting system and steam pasteurization.

\section{MATERIALS AND METHODS}

In this work, the species of microorganisms isolated directly from the $A$. subrufescens cultivation compost during Phase II of the composting were used as microbial inoculants.

\section{Isolates, culture media and microbiological inoculants}

The CS10 ( $A$. subrufescens) strain was used, belonging to the mycological collection of the Edible Mushrooms Laboratory of The University of Lavras (UFLA). The strain was reactivated and maintained in wheat agar (WA) medium until the production of the spawn. For the medium preparation, $1 \mathrm{Kg}$ of wheat grain was used, which was cooked in boiling water for $15 \mathrm{~min}$. Subsequently, $1 \mathrm{~L}$ of the broth was used, to which $15 \mathrm{~g}$ of agar and $15 \mathrm{~g}$ of yeast extract were added. The medium was autoclaved at $121^{\circ} \mathrm{C} / 30 \mathrm{~min}$. After cooling, the medium was poured into Petri dishes $\left(20 \mathrm{~mL}\right.$ plate $\left.{ }^{-1}\right)$. Right after, the strain were inoculated on the plates and incubated at the $25^{\circ} \mathrm{C} \pm 1 / 10$ days or until complete colonization. For spawn production, $6 \mathrm{~mm}$ discs from colonized plates were used to inoculate sterilized $500 \mathrm{~mL}$ glass flasks containing wheat grains, $2 \%$ calcium carbonate and $1 \%$ gypsum. The inoculated flasks were incubated at $25^{\circ} \mathrm{C} \pm 1 / 30$ days, or until complete colonization.

The following microbial inoculants were used: $S$. thermophillum (isolate UFLA 17/536), Bacillus megaterium (isolate UFLA 84i4 A3.5), Bacillus cereus (isolate UFLA 83i4 A4.4), all of them from the Laboratory of Edible Mushrooms, Department of Biology, The University of Lavras, Minas Gerais, Brazil. For the cultivation of $S$. thermophillum, oat meal agar was used, enriched with sorbose and kept at $40^{\circ} \mathrm{C}$ for seven days. After the incubation period, the spores were resuspended in saline solution (0.9\%) and counted in a Neubauer chamber. For the cultivation of the bacteria, the isolates were reactivated in nutrient broth, $\left(0.2 \% \mathrm{Na}_{2} \mathrm{HPO}_{4} ; 0.3 \% \mathrm{NaCl} ; 0.3 \%\right.$ meat extract; $0.5 \%$ peptone, $\mathrm{pH} 7.5$ ) and later cultivated in the same medium at $45^{\circ} \mathrm{C}$ for two days.

\section{Composting}

The compost was prepared according to the methodology described by Siqueira et al. (2009), using the following ingredients: Sugarcane bagasse $(45 \mathrm{~kg})$, coastcross hay $(45 \mathrm{~kg})$, wheat straw $(10 \mathrm{~kg})$, lime $(2 \mathrm{~kg})$, gypsum $(2 \mathrm{~kg})$ and ammonium sulfate $(1 \mathrm{~kg})$. The treatments were divided into five groups: Treatment 1, Without microorganism addition (control); Treatment 2, B. megaterium; Treatment 3, B. cereus; Treatment 4, S. termophyllum; and Treatment 5, B. megaterium, B. cereus and S. termophyllum (Table 1). All inoculants were used at a concentration of $10^{6} \mathrm{CFU} \mathrm{g}^{-1}$ of dry compost. This concentration was chosen in function of the results obtained by Silva et al. (2009), who reported a total microbial population during composting Phase I between $10^{7}$ and $10^{8} \mathrm{CFU} g$ -

1. The cultures were initially diluted in $10 \mathrm{~L}$ of water and followed by its addition to the compost on the $8^{\text {th }}$ day of the composting process.

At the end of the composting, the substrate was pasteurized at $60^{\circ} \mathrm{C} / 12 \mathrm{~h}$ of continuous steam as described by Siqueira et al. (2009). After cooling to room temperature, the compost was inocu- 
Table 1. Treatments used in the cultivation of $A$. subrufescens.

\begin{tabular}{cl}
\hline Treatment & Microbiological additive \\
\hline 1 & Without microorganism addition \\
2 & Bacillus megaterium \\
3 & Bacillus cereus \\
4 & Scytalidium termophyllum \\
5 & Bacillus megaterium, B.cereus, Scytalidium termophyllum \\
\hline
\end{tabular}

lated (10 g spawn $\mathrm{kg}^{-1}$ ), conditioned in polypropylene bags (2 $\mathrm{kg} / \mathrm{bag}$ ) and incubated at $25 \pm 3^{\circ} \mathrm{C}$ until complete colonization. The addition of the casing layer followed the same procedures described by Siqueira et al. (2009).

The first harvest took place 29 days after the induction of fructification and the total duration of the cultivation cycle was 117 days, with 4 harvesting cycles. On the day of maximum production, in the first flush, samples were collected for determination of the mushroom protein content for each treatment. The protein content was calculated from the total concentration of nitrogen, using a conversion factor of 4.38 . For the calculation of the total nitrogen content, the Kjeldahl method was used (Pardo et al., 2004; MAPA, 1994).

The production cycle, from the inoculation to the end of the harvest, was conducted under the temperature, relative humidity and carbon dioxide concentration conditions recommended for the selected species, maintaining the temperature at $25 \pm 3^{\circ} \mathrm{C}$ and the relative humidity at $80 \pm 4 \%$. The carbon dioxide concentration was reduced from $3000 \mathrm{ppm}$ during the compost colonization period to $700 \mathrm{ppm}$ for induction of the fructification, maintaining these conditions until the end of the cycle.

\section{Productivity and biological efficiency}

The productivity was calculated using the formula: [(Mass of fresh mushrooms/mass of moist compost) $x$ 100], while the biological efficiency was calculated using the formula: [(Mass of fresh mushrooms/mass of dry compost) $x$ 100], both expressed in percentage.

\section{Harvest and production analysis}

The mushrooms were picked daily according to their optimum state of commercial development, when the veil was stretched, but before the lamellae were exposed.

\section{Experimental design}

A completely randomized design (CRD) was used, in which the treatments corresponded to the variations of the microbial inoculants used for compost productio). For each treatment, 10 replicates were used, resulting in a total of 50 bags. The statistical program SISVAR ${ }^{\circledR}$ UFLA (Ferreira, 2000) was used, to which the data were submitted for variance analysis and the averages were compared by the Scott-Knott (5\%) test (Andrade et al., 2010).

\section{RESULTS AND DISCUSSION}

The biological efficiency and the productivity of $A$. subrufescens were influenced by the different treatments using microbiological inoculants added to the composting process (Table 2). The biological efficiency varied from 25.78 to $58.59 \%$ while the productivity reached values between 8.25 and $18.75 \%$. Colauto et al. (2010) reported that environmental characteristics, such as the type of casing layer, can influence the production of strains of $A$. subrufescens, suggesting that suitable conditions depend on the strain used in the cultivation cycle.

The biological efficiency of $A$. subrufescens can vary from 33.8 to $58.7 \%$, depending on the cultivation conditions, when the compost is prepared according to the conventional composting process (Phases I and II) (Eira, 2003). The data obtained in this work demonstrated compatible biological efficiency when any microbial inoculant was used. As reported before, the quality of the compost, besides its chemical composition, is directly related to its microbial community (Peters et al., 2000), mainly if the conventional system is not used.

With regard to the analyses of the quantitative parameters, significant differences were observed in all treatments, with the highest values being found in treatment 5 and the lowest values in Treatment 1 for the analyzed parameters: mushroom mass, biological efficiency and productivity (Table 2).

Significant differences were also observed among the different treatments regarding the dry matter and protein content. The highest dry matter and protein content were obtained in Treatment 5 (89.78 and $29.64 \%$, respectively). It is important to have edible mushrooms with high dry matter content: the higher the dry matter content, the lower the water content, and, consequently, higher will be the content of protein and other nutrient values, such as vitamins, minerals, carbohydrates, fibers, fats and amino acids (Chang and Miles, 2004). Therefore, in the present work, mushrooms with higher dry matter content showed higher protein content. In this way, we can suggest that the tested inoculants affected both agronomic parameters as well the food quality, since the lowest values for the dry matter and protein content were observed when no inoculants were used.

Considering the inoculants tested separately, the worst results were obtained with $B$. megaterium, followed by $S$. termophyllum and, then, by $B$. cereus. It is interesting because two species from the same genus have showed such differences (10.25 and $14.5 \%$ of productivity for $B$. megaterium and $B$. cereus, respectively). These results are an evidence for the potential to seek and test new 
Table 2. Quantitative and qualitative data for different $A$. subrufescens (CS10) cultivation treatments.

\begin{tabular}{|c|c|c|c|c|c|c|c|}
\hline \multirow[b]{2}{*}{ Treatment } & \multicolumn{5}{|c|}{ Quantitative data } & \multicolumn{2}{|c|}{ Qualitative data } \\
\hline & Total mushroom & Weight (kg) & Unit weight* & BE (\%) & $\begin{array}{c}\text { Productivity } \\
(\%)\end{array}$ & Dry matter (\%) & Protein (\%) \\
\hline 1 & $8 d$ & $0.135 \mathrm{e}$ & $16.88 c$ & $25.78 e$ & $8.25 \mathrm{e}$ & $87.33 e$ & $22.53 e$ \\
\hline 2 & $11 \mathrm{c}$ & $0.205 d$ & $18.63 b$ & $32.03 d$ & $10.25 d$ & $88.05 d$ & $23.38 d$ \\
\hline 3 & $14 b$ & $0.290 \mathrm{~b}$ & $20.71 a$ & $45.31 b$ & $14.50 \mathrm{~b}$ & $89.29 b$ & $27.22 b$ \\
\hline 4 & $13 b$ & $0.240 c$ & $18.46 b$ & $37.50 \mathrm{c}$ & $12.00 \mathrm{c}$ & $88.80 c$ & $25.80 c$ \\
\hline 5 & $20 a$ & $0.375 a$ & $18.75 b$ & $58.59 a$ & $18.75 a$ & $89.78 a$ & $29.64 a$ \\
\hline Mean & 13.2 & 0.249 & 18.69 & 39.84 & 12.75 & 88.65 & 25.71 \\
\hline
\end{tabular}

Means with the same letters in the same column do not differ statistically by the Scott-Knott test ( $5 \%$ of probability). *Average weight of mushrooms harvested from each treatment $(\mathrm{g})$.

species as microbial inoculants for the composting process aiming $A$. subrufescens cultivation. The productivity obtained in the treatments with inoculants separately ranged between 10.25 and $14.5 \%$, while the productivity reached in the control was $8.52 \%$. Siqueira et al. (2011) reported productivity values for $A$. subrufescens between 10.36 and $13.28 \%$ due to the initial content of nitrogen in the compost. Zied et al. (2010) obtained an average of $15.5 \%$, when compared different casing layers, while Colauto et al. (2010) reported an average productivity of $11.8 \%$ using alternatives to peat as casing layers. It is important to note that in all cited works, compost was used from conventional system of phases I and II, and a similar period of cycle cultivation. Therefore, the utilization of $B$. cereus as the only inoculant was sufficient to get a compost of similar quality to that produced in Brazil using the conventional process.

On the other hand, the best results were observed in the treatment 5 , characterized by the addition of the all microorganisms (B. megaterium, $B$. cereus and $S$. termophyllum) to the composting process, with a productivity of $18.75 \%$, which is more than twice as high as that in Treatment 1 (without inoculants). Not only the agronomic parameters, but also the protein content was superior in Treatment 5, when compared with other treatments. Probably, the utilization of a mixture of bacteria and fungus has contributed to obtain a compost of higher nutritional quality in comparison to the control. We must emphasize that even in the control there was a microbial succession, but we did not use the conventional Phase II, where termophilic microorganisms may grow uniformly in all compost, due to the uniform and constant temperature. Therefore, the addition of inoculants to the compost had a compensation effect for not using composting Phase II.

According to Coello-Castillo et al. (2009), substrates pre-colonized by $S$. thermophilum stimulated the colonization of $A$. bisporus. However, the productivity was negatively affected when the period of pre-colonization was longer than three days. That reason still remains without explanation, but it can be due to competition effects, since only one specie was used, resulting in the production of inhibitory secondary metabolites. In the present work, the utilization of a combination of microorganisms, besides the natural microbiota, probably resulted in equilibrium between different species during the composting process.

The positive effect of bacteria isolated from compost or casing layer on the mushroom growing and fruiting has been reported previously for the button mushroom $A$. bisporus (Reddy and Patrick, 1990; Zarenejad et al., 2012). Gill et al. (2005) reported a new automated system for button mushroom production in three phases, carried out inside a container, reducing the cycle cultivation from 109 days to 69 days, when compared to conventional system. According to the same authors, among other factors, these results were only possible because a mixture of bacteria and $S$. thermophilum were added to the compost. Inoculation of $S$. thermophilum during Phase II of the composting has been reported to provide higher productivity, with $A$. bisporus yields of up to three times higher in relation to the control (Vijay et al., 1999; Straatsma et al., 1994).

For $A$. subrufescens cultivation, the use of inoculants on casing layer has been reported (Young et al., 2012) but the present work is the first to report the utilization of inoculants for the composting process aiming a simpler technology which may be apropriate for small mushroom growers in developing countries.

\section{Conclusions}

The utilization of a combination of bacteria and fungus ( $B$. megaterium, $B$. cereus and $S$. termophyllum) may be used as an alternative to conventional Phase II to produce mushroom compost in a small scale aiming $A$. subrufescens cultivation by small mushroom growers.

\section{ACKNOWLEDGMENTS}

The authors express gratitude to the Fundação de Amparo à Pesquisa de Minas Gerais (FAPEMIG), 
Instituto Federal de Educação, Ciência e Tecnologia Baiano (IF Baiano) and Coordenação de Aperfeiçoamento de Pessoal de Nível Superior (CAPES processo: $5083 / 11-7$ ) for financial support.

\section{REFERENCES}

Ahlawat OP, Vijay B (2010). Potential of thermophilic bacteria as microbial inoculant for commercial scale white button mushroom (Agaricus bisporus) compost production. J. Sci. Ind. Res. 69 (12):948-955.

Andrade MCN, Chavari JL, Minhoni MTA, Zied DC (2010). Crescimento micelial in vitro de cinco linhagens de Agaricus bisporus submetidas a diferentes condições de temperatura. Acta Sci., Agron. 32(1):69-72.

Bechara MA (2007). Alternative mushroom production systems using noncomposted grain-based substrates. PhD dissertation, Pennsylvania State University, Department of Agricultural and Biological Engineering.

Chang ST, Miles PG (2004). Mushrooms: Cultivation, Nutritional Value, Medicinal Effect, and Environmental Impact. CRC Press, Boca Raton, FL. pp. 95-100.

Coello-Castillo MM, Sánchez JE, Royse DJ (2009). Production of Agaricus bisporus on substrates pre-colonized by Scytalidium thermophilum and supplemented at casing with protein-rich supplements. Bioresour. Technol. 100(19):4488-4492.

Colauto NB, Silveira AR, Eira AF, Linde GA (2010). Alternative to peat for Agaricus brasiliensis yield. Bioresour. Technol. 101:712-716.

Dias E, Labory CRG, Herrera KMS, Alves AA, Torres GA, Rinker DL (2008). Cytological studies of Agaricus brasiliensis. World J. Microb. Biotechnol. 24:2473-2479.

Dias, E. S. (2010). Mushroom cultivation in Brazil: challenges and potential for growth. Cienc. Agrotecnol. 34:795-803.

Eira, AF (2003). Cultivo do cogumelo Medicinal Agaricus blazei (Murrill) ss Heinemann ou Agaricus brasiliensis (Wasser et al). 1, pp 328-398.

Ferreira DF (2000). SISVAR - Sistema de análise estatística - Lavras, Programa computacional. DCE, UFLA.

Gill P, Elmekkawy T, Strong D (2005). Productivity improvement in mushroom plants. The Canadian Society for Engineering in Agricultural, Food, and Biological Systems. 5:101.

Kerrigan RW (2005). Agaricus subrufescens, a cultivated edible and medicinal mushroom, and its synonyms. Mycologia 97:12-24.

Kerrigan RW (2007). Inclusive and exclusive concepts of Agaricus subrufescens peck: a reply to Wasser et al. Int. J. Med. Mushrooms 9:79-83.

Matute RG, Figlas D, Curvetto N (2011). Agaricus blazei production on non-composted substrates based on sunflower seed hulls and spent oyster mushroom substrate. World J Microbiol Biotechnol. 27:13311339.

MINISTERIO DE AGRICULTURA, PESCA Y ALIMENTACIÓN. (1994). Métodos Oficiales de Análisis. Madrid: MAPA. 1:532.

Oei P. (2003). Mushroom cultivation - Appropriate technology for mushroom growers. 3:429.

Pardo A, De Juan AJ, Pardo J, Pardo JE (2004). Assessment of different casing materials for use as peat alternatives in mushroom cultivation. Evaluation of quantitative and qualitative production parameters. Spanish J. Agric. Res. 2(2):267-272.
Peters S, Koschinsky S, Schwieger F, Tebbe CC (2000). Succession of microbial communities during hot composting as detected by PCRsingle-strand-conformation polymorphism-based genetic profiles of small-subunit rRNA genes. Appl. Environ. Microbiol. 66(3):930-936.

Reddy MS, Patrick ZA (1990). Effect of bacteria associated with mushroom compost and casing materials on basidiomata formation in Agaricus bisporus. Canadian J. Plant Pathol. 12(3):236-242.

Salar RK, Aneja KR (2007). Significance of thermophilic fungi in mushroom compost preparation: effect on growth and yield of Agaricus bisporus (Lange) Sing. Int. J. Agric. Technol. 3(2):241-253.

Silva CF, Azevedo RS, Braga C, Silva R, Dias ES, Schwan RF (2009). Microbial diversity in a bagasse-based compost prepared for the production of Agaricus brasiliensis. Braz. J. Microbiol. [online] 40 (3):590-600.

Sinden JW, Hauser E (1950). The short method of mushroom composting. Mushroom Sci. 1:52-59.

Siqueira FG, Dias ES, Silva R, Martos ET, Rinker DL (2009). Cultivation of Agaricus blazei ss. Heinemann using different soils as source of casing materials. Sci. Agric. 66 (6):827-830.

Siqueira FG, Martos ET, Silva EG, Silva R, Dias ES (2011). Biological efficiency of Agaricus brasiliensis cultivated in compost with nitrogen concentrations. Horticultura Brasileira 29:157-161.

Straatsma G, Samson RA, Olijnsma TW, Gerrits JPG, Op Den Camp HJM, Griensven LJLD Van (1994). Ecology of thermophilic fungi in mushroom compost, with emphasis on Scytalidium thermophilum and growth stimulation of Agaricus bisporus mycelium. Appl. Environ. Microbiol. 60 (2):454-458.

Vajna B, Nagy A, Sajben E, Manczinger L, Szijartó N, Kádár S, Bordás D, Marialigeti K (2010). Microbial community structure changes during oyster mushroom substrate preparation. Appl Microbiol Biotechnol. 86:367-375.

Vijay B, Sharma SR, Verma RN, Lakhanpal TN (1999). Role of themophilic fungi in compost production for White Button mushroom (Agaricus bisporus). In: International Conference of Mushroom Biology and Mushroom Products. 3, p. 23.

Wasser SP, Didukh MY, Amazonas MAL, Nevo E, Stamets P, Eira AF (2002). Is a widely cultivated culinary-medicinal mushroom indeed Agaricus blazei Murril? Int. J. Med. Mushrooms 4:267-290.

Wasser SP, Didukh MY, Amazonas MAL, Nevo E, Stamets P, Eira AF (2005). Is a widely cultivated culinary-medicinal royal sun Agaricus (Champignon do Brasil, or the himematsutake mushroom) Agaricus brasiliensis $\mathrm{S}$. Wasser et al. indeed a synonym of $A$. subrufescens peck? Int. J. Med. Mushrooms. 7:507-511.

Young LS, Chu JN, Young, CC (2012). Beneficial bacterial strains on Agaricus blazei cultivation. Pesq. agropec. bras. 47:815-821.

Zarenejad F, Yakhchali B, Rasooli I (2012). Evaluation of indigenous potent mushroom growth promoting bacteria (MGPB) on Agaricus bisporus production. World J. Microbiol. Biotechnol. 28:99-104.

Zied DC, Minhoni MTA, Kopytowski-Filho J, Andrade MCN (2010). Production of Agaricus blazei ss. Heinemann (A. brasiliensis) on different casing layers and environments. World J. Microbiol. Biotechnol. 26:1857-1863. 